\title{
The Influence of Micro Industry Entrepreneurship in the Process of Poverty Alleviation (Studies in the Food Industry Center at Southeast Sulawesi)
}

\author{
Abd. AzisMuthalib, LM. Harafah, Muh. Yani, Rostin, and Mahmudin AS. \\ UniversitasHalu Oleo, Southeast Sulawesi Indonesia 93232
}

\begin{abstract}
This study aims to: (1) Determine the micro entrepreneurial industry in Southeast Sulawesi. (2) Determine the influence of micro-entrepreneurial industry towards poverty alleviation in Southeast Sulawesi. The results showed that: (1) Entrepreneurship micro businesses in the food industry in Southeast Sulawesi in view of the dimensions of entrepreneurial attitudes and entrepreneurial competence quite good. While the dimensions of personal value very well. As for the dimensions of motivation tried quitegood. The low dimensional entrepreneurial motivation micro businesses in the food industry of Southeast Sulawesi province than other dimensions due to micro businesses generally do not have a target to pursue greater profits. They underwent a effort to meet the needs of families with no plans to expand its business for the future may develop into small and medium enterprises. (2) Entrepreneurship significant effect with positive direction towards alleviation of poverty in Southeast Sulawesi. This means that the proxy entrepreneurial attitudes to entrepreneurship, entrepreneurship motivation, entrepreneurial competence, personality and values can alleviate poverty in the form of an increase in income, consumption expenditure, an increase in household assets and increase spending on education and health.
\end{abstract}

Keywords: Entrepreneurship, Poverty Alleviation.

\section{Introduction}

In economic development, the problem of poverty is still the focus of attention in various countries in the world. Because it is within the scope of the International, poverty on the agenda contained in the Millennium Development Goals (MDGs). In Indonesia, efforts to alleviate poverty have been carried out through various programs and projects both at the central and regional levels. But nevertheless the number of poor people is still quite large with the rate of decline is still slow.

Over the past two years the poverty rate in Indonesia, both in absolute terms and relative decline. The number of poor people in Indonesia in 2012 was recorded 28594.60 thousand inhabitants declined in 2013 into 28553.9 thousand or a decrease of 40.67 thousand people ( 0.14 percent). Relatively poor people in Indonesia has decreased from 11.66 percent in 2012 to 11.47 percent in 2013, down by 0.19 percent. Decrease in the number of poor people in Indonesia, both in absolute and relative terms is still very small at less than 0.2 percent.

In Southeast Sulawesi province the number of poor is likely to increase both in absolute and relative terms. The number of poor people in Southeast Sulawesi in 2012, there were 316.33 thousand inhabitants increased in 2013 to 326.71 thousand, an increase of 10, 38 thousand, up 3.28 percent. In relative terms the number of poor increased from 13.71 in 2012 to 13.73 percent in 2013, an increase of 0.02 per cent of the population. This means that poor people in Indonesia as a whole as well as in Southeast Sulawesi province in particular during the last two years is still quite large. Therefore, it still required a variety of alternative solutions in an effort to solve the problem of poverty.

The efforts made by the government through various poverty alleviation programs both central and local government, yet provide optimal results in alleviating poverty. Supposedly programs disbursed by the government to alleviate poverty with substantial budget have been able to reduce the poverty rate siginifican. But in reality both national poverty rate (Indonesia) as well as in Southeast Sulawesi province is still relatively large. In various international forums, the alleviation of poverty through entrepreneurship development has been much discussed. At a meeting of Asian entreprise leaders also stressed that the role of entrepreneurship in poverty reduction can no longer be underestimated.

Poverty alleviation by entrepreneurial been decomposed by Fong Chan Onn clearly (2013). He stated that entrepreneurship can no longer be underestimated due to the development of increasingly important in the poverty alleviation goals last few decades become a problem together for developing countries in the Asia Pacific region. Chan Onn who also served as Minister of Human Resources Malaysia added that the essential role of entrepreneurship in poverty alleviation increasingly crystallized as open access in order to improve educational standards at the same level of employment ((http // www geogle com). 
Minister of Cooperatives and SMEs Sharif Hasan (2013) asserts that with the increasing number of entrepreneurs, will be more open to expanding employment opportunities available to job seekers who generally remained in the productive age range. He explained that the dual advantage to be gained from an increase in the number of entrepreneurs in Indonesia.

In addition to alleviating poverty through the minimization of unemployment, another advantage is the increased absorption of labor so that the wheels will continue to run and the economy is expected to continue to squirm. So there is no reason to postpone the increase in intensive entrepreneurial sector in Indonesia to poverty reduction and achievement of better economic potential considering the abundant number of human resources has not been fully utilized in the independent entrepreneurial sector.

Research on the effect of entrepreneurship on poverty reduction is still scarce. However, studies related to the causal relationship between entrepreneurship and poverty reduction have been carried out. To prove the statements were presented at various international forums on the role of entrepreneurship in poverty alleviation still needs research.

Muhammadsuhaimee (2012) in his research on the causal relationship between entrepreneurial poverty and income inequality in Thailand found that the establishment of the company as a proxy for entrepreneurship led to an increase of poverty in Thailand.Ludovick in research on the alleviation of poverty through entrepreneurship and innovation found that entrepreneurial reduce poverty significantly. Poverty fell by a much greater magnitude when interacting with entrepreneurial innovation.Lee and Tsang (2001) that the success of the business is highly dependent role of the entrepreneur or entrepreneurial itself, and the entrepreneurial human factor plays an important role in addition to other factors critical. Suryana (2003) explains that the success or failure depends on the ability of entrepreneurial private entrepreneurs. This means that the success or failure of a business is highly dependent on entrepreneurial abilities possessed by the manager / manager of the business.

Seongbae Lim (2002) asserts, the development of the concept of entrepreneurial orientation is very necessary in a small company. It is important for the personal attributes of the owner of that form entrepreneurial orientation has a strong influence on the performance of the business. The dimension is reflected in the attitudes and behavior, such as: autonomy, risk, innovative, and compete aggressively with putting personal attributes that exist in the business owner. Similarly (Zahra and Garvis, 2000; Lumpkin and Dess, 2001; Wiklund and Sephered, 2005) suggests that small companies oriented entrepreneurship allows to carry out their activities better than competitors. He also explained that the entrepreneurial orientation can contribute to business performance.

Entrepreneurial role in promoting economic growth, expansion of employment and income distribution is very important. In line with that Gregory C. Chow, 2010, explaining that the Enterprise has prompted changes in the Chinese economy. In this case the enormity of the economic growth in China is mainly due to the development of entrepreneurship. This means that entrepreneurship can be one alternative solution in the fight against poverty.

Data from the Department of Industry and Trade of Southeast Sulawesi Province shows that microenterprises, especially the food industry centers scattered in the food industry in Southeast Sulawesi has increased from year to year. The number of micro enterprises, especially the food industry centers scattered in the food industry in Southeast Sulawesi in 2011 recorded 124 business units increased in 2012 to 138 business units, up 11.29 percent.

Preliminary results obtained illustrate that micro enterprises food industry is highly prospective, because the industry is in addition to not require capital investment and large enough, also do not require high skills and technology. This means that micro enterprises food industry can be implemented with a simple technology that does not require high skills. Food industry business investment costs ranging from $\$ 1$ million to USD 10 million in working capital from Rp.500 thousand to Rp.2.5 million. In addition, micro enterprises food industry can benefit between 20-40 percent, with a level of earned income can reach Rp.4 million to Rp.12 million per month, or USD 48 million to 144 million per year.To determine whether entrepreneurial significant effect on poverty reduction is still required a more in-depth research.

\section{Methods}

This type of research is the study of associative inni. According Sugiyono (2005) is the associative research study aimed to determine the effect between two or more variables by examining the causal relationship between variables. In this study will be assessed the effect of entrepreneurial variable to variable poverty alleviation. The research was conducted in Southeast Sulawesi province with the object of research in the food industry. Research location held in the food industry center in southeast Sulawesi province.The population of this study are all micro-entrepreneurs in the food industry food industry center in Southeast Sulawesi province, amounting to 138 units of micro-enterprises (data from the Department of Trade and Industry of South East Sulawesi in 2013). The sampling technique used in this study is saturated sample or 
census that took all the population as a sample.The variables of this study consists of:Exogenous variables (X), namely entrepreneurship and endogenous variables (Y) of poverty reduction.

\section{Operational Definition of Variables}

Entrepreneurship is the ability to think of creative, innovative behavior and acting productive, so it can run a micro business that leads to the creation of employment opportunities and the improvement of people's income. This variable is a variable that affects the (exogenous variables), this variable was not measured directly so it is necessary that the measuring indicators: attitudes to entrepreneurship, entrepreneurship motivation, entrepreneurial competence, and the value of personality.

Poverty reduction referred to in this research that changes in the level of economic welfare or improvement of household at a better rate as a result of their entrepreneurial spirit. This variable is not measured directly but is measured through indicators: revenue growth rate, the growth rate of consumption expenditure, household asset growth rate, rate of growth in the number expenditure on education, as well as the rate of growth in the number of health expenditure.

Type and Data Collection Techniquesused in this study are primary data and secondary data.Collecting data using the following techniques:Questionnaire, Interview, Instrument Research, The research instrument used questionnaires and interview guidelines. The data analysis technique used is a structural equation model (structural equation modeling or SEM) with the help of software AMOS 18.0.

\section{Test Model}

\section{Results and Discussion}

Based on the method of determining the value of the model, the first model testing variables are grouped into exogenous variables (exogenous variables) and endogenous variables (endogenous variable). Exogenous variable is a variable whose value is determined outside the model. While the endogenous variable is a variable whose value is determined by an equation or model established relationships included in the exogenous variables is an entrepreneurial group. While classified as an endogenous variable is the alleviation of poverty. Model is said to be good when the development of theoretical models hypothesis is supported by empirical data. Based on the model further modification and the results shown in the Figure 1.

Based on the evaluation of the models in Table 7, it can be said that the model developed in this study has been acceptable, because it tends to fit the empirical data. It is characterized by the value of Chi-Squared small / well in the amount of 281.380, amounting to 0.979 TLI and RMSEA value of 0.024 , which is above the values of the cut of value, so in general the values of the results of the model can be said to be feasible.

It refers to the principle of parsimony (Arbuckle and Wothke, 1999 in Solimun, 2004) that if there are one or two criteria of goodness of fit that has met the expected value (cut of value), then the model can already be said to be good or development as a hypothetical model conceptual and theoretical can be said to be supported by empirical data. It can be concluded that the structural model developed in this study are in accordance with the results of observation so as to allow for the direct analysis between variables influence the construct and conduct hypothesis testing.

\section{Entrepreneurship of Micro Industry}

Entrepreneurship in micro businesses in the food industry in Southeast Sulawesi in view of the dimensions of entrepreneurial attitudes and entrepreneurial competence quite good. While the dimensions of personal value very well. As for the dimensions of motivation tried quite good. The low dimensional entrepreneurial motivation micro businesses in the food industry of Southeast Sulawesi province than other dimensions due to micro businesses generally do not have a target to pursue greater profits. They underwent a effort to meet the needs of families with no plans to expand its business for the future may develop into small and medium enterprises. 


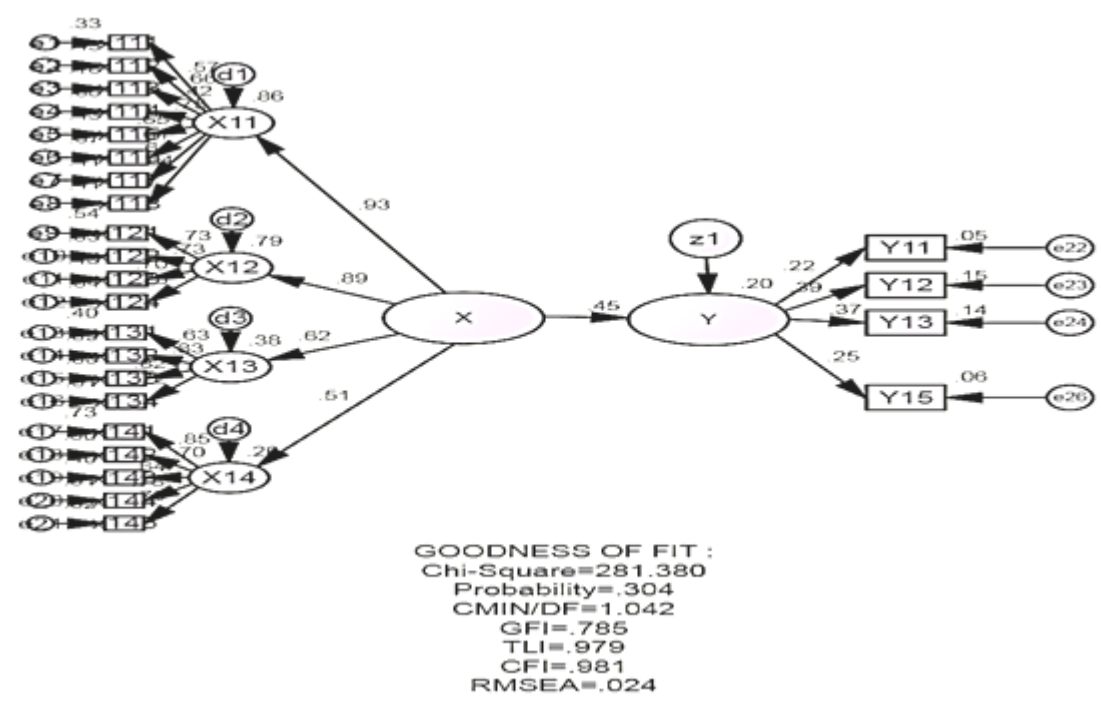

Figure 1. SEM Model Full Picture (after modification)

Entrepreneurial attitude dimension is the dimension of the most powerful in shaping the entrepreneurial variable, while the value of personality is a dimension which is less powerful in shaping the entrepreneurial variable. It indicates that the most important factor in entrepreneurship is perceived entrepreneurial attitude of flexibility sociable, hard work and innovative, self-confidence, put my trust in God, to respond to the opportunities, take risks, have the creative spirit in trying, have achieved results orientation, and earnest attitude towards business managed. So entrepreneurship is not enough to simply rely on the personality factor of honesty, responsibility, trust, gratitude and trusts, as well as diligent and tenacious. So the most important in entrepreneurship is an entrepreneurial attitude.

Facts on the field found that entrepreneurial motivation has not been fully reflected either through entrepreneurial attitude that is not fully motivated achieve better performance by overcoming obstacles and challenges that businesses are managed, has not been fully tried with motivation to achieve business growth is managed, not fully have ideals goals and expectations to be realized and not yet fully have the instinct able to do a business activity.

It is empirically also proves that entrepreneurship run still has limitations characterized by the presence of a small proportion of respondents that assessment is not good which is about $14.45 \%$. In connection with these policies need to get attention is to increase motivation by means of overcoming obstacles to entrepreneurship and business challenges, improve business growth, as well as the hardest to realize the ideals and expectations for success in improving the income, consumption, household assets, education spending and health.

\section{The Effect of Entrepreneurship on Poverty Alleviation}

Hypothesis testing variables influence entrepreneurship to poverty reduction based on the results of data processing can be seen in which the recapitulation as in table 1.Based on data from Table 1, it can be done hypothesis testing as follows:

Entrepreneurship significant effect on poverty alleviation in Southeast Sulawesi. The results of the analysis in Table 1 shows that the path coefficient entrepreneurial influence on poverty in Southeast Sulawesi province amounted to 0.450 with a probability value $=0.031<0.05$. Thus, the hypothesis can be accepted, which means that a positive and significant effect of entrepreneurship on poverty in Southeast Sulawesi Province. This means that the proxy entrepreneurial attitudes to entrepreneurship, entrepreneurship motivation, entrepreneurial competence, personality and values can alleviate poverty in the form of an increase in income, consumption expenditure, an increase in household assets and increase spending on education and health.

Table 1. Summary of Results of Data Processing

\begin{tabular}{|l|l|l|l|}
\hline Path & Path Coef. & Prob. & Status \\
\hline Entrepreneurship $(\mathrm{X}) \rightarrow$ poverty reduction $(\mathrm{Y})$ & 0,450 & 0,031 & Signifikan \\
\hline
\end{tabular}

The condition is caused because of the perceived entrepreneurial attitudes to entrepreneurship, entrepreneurship motivation, entrepreneurial competence and personality were in good condition. This is because the descriptive majority of respondents have a good entrepreneurial centers, especially in the food industry in Southeast Sulawesi. Therefore, the achievement of a good entrepreneurial maintained even expected in the future be improved. 
Empirical evidence indicates that personality should take precedence value or precedence in the implementation. This means that the value of personality that is reflected through honesty and moral responsibility in business activities, attitude of trust, gratitude and trust in Allah SWT can be used as a basis for the development of entrepreneurship. Besides, the attitude of diligent, tenacious and unyielding in trying also an element of personality value can ensure the implementation of entrepreneurship.

Empirical facts also prove that the entrepreneurial attitude that has been set, also good. This condition show that entrepreneurs have the attitude of flexibility to get along, work hard to find new ways for future business development (innovative), have the confidence to step up efforts to put my trust in God, to respond to business opportunities that exist, dare to take and accept risks occurs, has a soul and a creative attitude in trying, orientation results to be achieved in business and have earnest attitude towards what is done.

In addition, empirical facts prove also that entrepreneurial competence has been applied properly. This means that entrepreneurs have the professional capability in accordance with the business that occupied, able to communicate and relate to others for the betterment of business managed, have the ability to anticipate the opportunities that exist and are able to create business opportunities and have the ability to organize business managed.

Entrepreneurship which has been run by the well was able to alleviate poverty implemented in increase in income, consumption expenditure, household assets, spending on education and health spending.

From the change / increase in revenue indicates that the amount of revenue three years ago the average of Rp. 45,410,869.57. With a minimum value of Rp.8.000.000-, a maximum of Rp. 300,000,000,- or a total 6.266.700.000.- While the current year average of Rp. 56,619,565.22. With a minimum value of Rp.9,000,000,a maximum of Rp.500,000,000,- or a total of USD 7.8135 billion,-- Average revenue growth over the last 3 years increased by 24.68 per cent

Associated with changes in consumption, the facts prove that the consumption of the last 3 years on average Rp. 18,457,246.38,- with 3.500.000- minimum value, maximum 170,000,000,- or a total of 2.5471 billion,-. While the current year average of Rp. 22,963,405.80,- with a minimum of 6,000,000,- maximum $25,000,000$,- or a total of 3.16895 billion,-- Average consumption growth over the last 3 years increased by 24.41 percent.

In connection with the change in household assets, the fact remains that the asset 3 years ago the average of Rp. 90,760,869.57 with a minimum value of USD 15,000,000, up to Rp.175 million,- or a total of USD 12.5255 billion,-. While the current year average of Rp. 107713 913,- with a minimum value of Rp.19,000,000,- a maximum of Rp.250,000,000,- or a total of USD 14.79 billion,-. The growth of household assets on average over the last 3 years increased by 18.68 percent.

On the expenditure side changes in education, it was found that education spending 3 years ago the average of Rp. 5,608,333.33 USD 400.000- minimum value, maximum of Rp.50,000,000,- or a total of USD 773950 000,-. The current year average of Rp. 7,492,536.23,- with a minimum value of Rp.700,000,- a maximum of Rp.60,000,000,- or a total of USD 1.03397 billion,-. Education expenditure growth over the last 3 years increased by an average of 33.60 percent.

Meanwhile, in terms of health expenditure, suggesting that health spending 3 years ago the average of Rp. 359,818.84 with a minimum value of Rp.40,000,- a maximum of Rp.1,500,000,- or a total of USD 49.655 million,-. While the current year average of Rp. 489.384,06- with a minimum value of Rp.50,000,- a maximum of Rp.2,000,000,- or a total of USD 7.535 million,-. The growth in health spending over the past three years increased by an average of 36.01 percent.

The results are consistent with the views expressed by Ali Yasin (2013) that entrepreneurship contributes to poverty reduction. Ludovick in research on the alleviation of poverty through entrepreneurship and innovation found that entrepreneurial reduce poverty. In Asia Entreprise leaders meeting in 2013 explained that the role of entrepreneurship in poverty reduction can no longer be underestimated. Therefore, the primary focus on poverty reduction is to develop entrepreneurship. These results reject the results of empirical research conducted by Muhammadsuhaimee (2012) that the establishment of the company as a proxy for entrepreneurship led to an increase of poverty. Further support Ludovick research which found that entrepreneurial reduce poverty significantly. Adofu (2013) research results show that $65 \%$ of respondents stated that the lack of entrepreneurial skills among youth is closely related to the high levels of poverty. Fong Chan Onn (2013) states that entrepreneurship can no longer be underestimated due to the development of an increasingly essential to reduce poverty. Nevertheless, these results reject research Ali Yasin (2013) who found that there was a weak positive correlation between entrepreneurship developmentwith poverty reduction. 


\section{Conclusion}

\section{Conclusions and Recommendations}

Entrepreneurship of micro industrial businesses in Southeast Sulawesi quite good. Because it's a good entrepreneurial achievement maintained even expected in the future be improved.Entrepreneurship significant effect with positive direction towards the alleviation of poverty in Southeast Sulawesi. This means that the proxy entrepreneurial attitudes to entrepreneurship, entrepreneurship motivation, entrepreneurial competence, personality and values can alleviate poverty in the form of an increase in income, consumption expenditure, an increase in household assets and increase spending on education and health.

\section{Suggestion}

1. Entrepreneurship needs to be included as one of the most important part of poverty alleviation programs. To inculcate entrepreneurship, entrepreneurship education should not only be given to higher education, but also must be given at all levels of education.

2. Should the entrepreneur attention to aspects of entrepreneurship motivation by overcoming obstacles and challenges of the business, increase business growth, as well as the hardest to realize the ideals and expectations for success in business.

3. The role of the government to the promotion and development of micro enterprises in particular the food industry related institutions still need to be improved in order to attempt the food industry can contribute significantly to the local economy.

\section{References}

[1]. Abu, Ikponmwosa Noruwa dan Ezike John Emeke. 2012. The Role and Sustainability of Microfinance Banks Is Reducing Poverty and Development of Entrepreneurship inUrban and Rural Areas in Nigeria. University of Lagos, Nigeria. International Journal of Business Administration. Vol.3, No.3; May 2012 pp 33-40.

[2]. Adofu, Ilemona. 2013. Alleviating Poverty Through The Use of Entrepreneurship Skill Acquisition in Kogi State, Nigeria. International Open Journal of Economics. Vol. 1. No. 2. August 2013. PP: 14-23

[3]. Aedy, Hasan. 2007. Indahnya Ekonomi Islam. Alfabeta Bandung.

[4]. Aedy, Hasan. 2010. Strategi dan Solusi Pengentasan Kemiskinan di Daerah Sulawesi Tenggara.Universitas Muhammadiyah Kendari, Kerjasama Dengan Badan Penelitian dan Pengembangan Provinsi Sulawesi Tenggara.

[5]. Ali Yassin Shaeikh Ali. 2013. Entrepreneurship Development and Poverty Reduction. Empirical Survey From Somalia. American International Journal of Social Science. Vol. 2 No. 3; May. 2013

[6]. Alma, Buchari.2007. Kewirausahaan, Menumbuhkan Jiwa Wirausaha Bagi Mahasiswa dan Masyarakat Indonesia.Alfabeta, Bandung.

[7]. Catur Panggih Pamungkas. 2009. Keterkaitan Pertumbuhan Ekonomi dengan Kemiskinan di Jawa Timur: Suatu Pendekatan Spasial.JurnalRisetEkonomiTahun I/No.3/Desember 2009.

[8]. Cordelia Mason. 2011. Entrepreneurship Education and Research : Emerging Trends and Concern. Journal of Global Entrepreneurship. January 2011.Volume 1. Numbe 1.

[9]. Drucker, P.F. 1985, Innovation and Entrepreneurship : Practice and principles, New York : Harper and Row.

[10]. Fong Chan Onn. 2013. Pengentasan Kemiskinan dengan Wirausaha. Warta Wirausaha http//www geogle com. 15 Juli 2013.

[11]. Gregory, C, Chow. 2010. MemahamiDahsyatnyaEkonomi China., AlihBahasaRahmaniAstuti. TigaSerangkaiPustakaMandiri. Jakarta.

[12]. Khandker, S.R. 1998, Fighting poverty with microcredit (Experience in Banglades), Oxford University Press, World Bank, P-2.

[13]. Lee, D.Y. danTsang. 2001. The Effects of Entrepreneurial, Personality, Background and Net Work Activities on Venture Growth. Journal Of Management Studies. Vol. 38(4) 583.

[14]. Lumpkin, G.T. dan Dess, G.G. 2001. Linking two dimension of entrepreneurial orientation to firm performance : The moderating role of environment and industry life cycle, Journal of Business Venturing, 16(5), pp. 429-451.

[15]. Machfoed, mas'ud. 2008. Kewirausahaan, Metode, Manajemen, dan Implementasi. Edisi 2005/2006. BPFE UGM. Yogyakarta.

[16]. Machfoed, Mas'ud. 2004. Kewirausahaan : Suatu Pendekatan Kontenporer. Unit Penerbit dan Percetakan Akademi Manajemen Perusahaan YKPN. Yogyakarta.

[17]. Meredith Geoffrey G. 2006. Kewirausahaan Teori dan Praktik.PustakaBinamanPressindo, Jakarta

[18]. Muhammadsuhaimee Yanya. 2012. Causal Relationship between Entrepreneurship Poverty and Income Inequality In Thailand.International Journal of Trade and Finance. Vol. 3 No. 6. Desember 2012.

[19]. Patrick J.Murphy. 2009. Entrepreneurship Theory and the Poverty of Histroricism. Journal of Management History. Vol. 15.No. 2. Pp 109-133

[20]. Saiman Leonardus, 2009. Kewirausahaan, Teori, Praktik dan Kasus-Kasus. Salemba Empat, Jakarta.

[21]. Sandjojo, I. 2004. Pengaruh Lingkungan Usaha, Sifat Wirausaha dan Motivasi Usaha Terhadap Pembelajaran Wirausaha, Kompetensi Wirausaha dan Pertumbuhan Usaha Kecil di Jawa Timur. RingkasanDisertasi. ProgramPascasarjanaUniversitasBrawijayaMalang.

[22]. Seongbae, Lim. 2002. Entrepreneurial Orientation And the Performance of Service Business, St, Mary's University. One Camino Santa Maria, San Antonio, TX 78228.

[23]. Suharto, E.2003, Pekerjaan Sosial dan Paradigma Baru Kemiskinan, www.policy.hu/suharto/makindo28.html.

[24]. Suryana. 2003. Kewirausahaan. Pedoman Praktis, Kiat dan Proses Menuju Sukses. Salemba Empat, Jakarta.

[25]. Wicklund, \&Sepherd, D., 2005. Entrepreneurial Orientation and Small Business Performance: A configurational approach. Juornal of Business Venturing, 20(1), pp. 71-91.

[26]. Zahra, S.A., \&Garvis, D.M., 2000. Entrepreneurship and firms performance: The Moderating effect of international environmental hostility. Journal of Business Venturing, 15(5), pp. 469-492. 